\title{
PERKEMBANGAN SINTAKSIS ANAK USIA EMPAT TAHUN (KAJIAN PSIKOLINGUISTIK)
}

\author{
Oleh: \\ ${ }^{1}$ Frinawaty L. Barus, ${ }^{2}$ Safinatul Hasanah, ${ }^{3}$ Atika Wasilah \\ 1,2,3 Prodi Pendidikan Bahasa dan Sastra Indonesia \\ Surel: 1frinabarus@unimed.ac.id,2finahrp@gmail.com, 3atikawasilah@yahoo.co.id, \\ ${ }_{1,2,3}$ Universitas Negeri Medan
}

\begin{abstract}
ABSTRAK
Tujuan penelitian ini adalah untuk mengetahui perkembangan sintaksis anak berdasarkan kajian Mean Length of Utterance (MLU) yang dikemukakan oleh Brown. Selain itu, tujuan penelitian ini adalah untuk melihat jenis kata dan pola kalimat yang telah dapat diproduksi. Metode yang digunakan dalam penelitian ini adalah metode deskriptif kualitatif. Data dalam penelitian ini adalah anak dengan usia 48 bulan (4 tahun). Analisis data dilakukan dengan kualitatif. Hasil penelitian menunjukkan bahwa MLU anak tersebut berada pada tahap lima dengan MLU 5.9. Dari tingkatan MLU tersebut terlihat bahwa anak tersebut sudah sesuai perkembangan sintaksisnya berdasarkan MLU. Jenis kata yang telah dapat dihasilkan adalah verba, adjektiva, nomina, pronomina, numeralia, adverbia, interogativa, demonstrativa, preposisi, dan konjungsi. Sedangkan untuk jenis kata artikula belum dapat dihasilakan. Pola kalimat yang telah dihasilkan yaitu: $\mathrm{S}+\mathrm{P}, \mathrm{S}+\mathrm{P}+\mathrm{Ket}$, Ket $+\mathrm{S}+\mathrm{P}+\mathrm{Ket}, \mathrm{S}+\mathrm{P}+\mathrm{O}+\mathrm{Ket}$, dan $S+P+k j+S+P$.
\end{abstract}

Kata Kunci: Perkembangan Sintaksis dan MLU (Mean Length of Utterance)

\section{A. PENDAhULUAN}

Proses pemerolehan bahasa pada anak merupakan suatu hal yang sangat menakjubkan dalam satu bagian pada kehidupan anak - anak. Bagaimana anak-anak dapat menguasai bahasa pertamanya atau sering disebut sebagai bahasa ibu tanpa proses pembelajaran merupakan hal yang sangat luar biasa. Semua anak yang normal atau mengalami pertumbuhan yang wajar akan memperoleh suatu bahasa dalam proses perkembangannya yaitu bahasa pertama atau bahasa ibu dalam tahun-tahun pertama kehidupannya. 
Perkembangan bahasa pada anak juga merupakan bagian yang menuntut perhatian khusus untuk diteliti. Perkembangan bahasa pada anak meliputi perkembangan fonologi, morfologi, sintaksis, semantik, dan konseptual dari bahasa pertamanya. Memang diakui bahwa disadari ataupun tidak, sistem-sistem linguistik dikuasai dengan pantas oleh individu anak-anak walaupun umumnya tidak dalam pengajaran formal. Pada tahap perkembangan sintaksis, anak akan mengenal kalimat satu kata, dua kata, dan selanjutnya, hingga anak mampu mengunakan kalimat yang lengkap sturukturnya. Ada berbagai alat ukur untuk mengetahui perkembangan sintaksis bahasa pada anak. Salah satunya adalah MLU ( Mean Length of Utterance), untuk mengetahui perkembangan bahasa pada anak terutama dalam tataran sintaksis.

$M L U$ merupakan satu konsep yang digunakan untuk mengukur produk bahasa yang dapat diproduksi oleh anak. Pada umumnya, penghitungan $M L U$ dilakukan dengan membagi bilangan morfem dengan bilangan ujaran. Artinya, jumlah bilangan ujaran yang diperlukan ialah 50 atau 100 ujaran utama anak. Semakin tinggi $M L U$ anak maka semakin tinggilah penguasaan berbahasa anak tersebut. Sebaliknya, semakin rendah penguasaan MLU seorang anak maka makin rendah penguasaan bahasa anak.

Penelitian mengenai pemerolehan sintaksis pada anak menggunakan kajian MLU sudah pernah dilakukan. Diantaranya adalah Marsis dan Witri (2018) hasil penelitian menunjukkan bahwa dari delapan anak yang diteliti dua anak sesuai dengan ketetapan Brown, tiga lebih tinggi dari ketetapan Brown, dan tiga lebih rendah dari ketetapan Brown. Selain itu, Nasution ( 2019) memperlihatkan bahwa adanya kesesuain perkembangan sintaksis anak dengan yang dikemukakan oleh Brown.

Berdasarkan uraian di atas penelitian ini bertujuan untuk mengetahui perkembangan sintaksis anak berdasarkan MLU (Mean Length of Utterance), jenis kata, dan pola kalimat yang telah dapat dihasilkan oleh anak.

\section{B. KAJIAN PUSTAKA}

Pemerolehan bahasa atau akuisisi adalah proses yang berlangsung di dalam otak seorang anak ketika dia memperoleh bahasa pertamanya atau bahasa ibunya. Setiap anak yang normal akan belajar bahasa pertama (bahasa ibu) dalam tahun-tahun pertamanya dan proses itu terjadi hingga kira-kira umur lima tahun. Dalam proses perkembangan, semua anak manusia yang normal paling sedikit memperoleh satu bahasa alamiah. Dengan kata lain, setiap anak yang normal atau mengalami pertumbuhan yang wajar memperoleh sesuatu 
bahasa yaitu bahasa pertama atau bahasa ibu dalam tahun-tahun pertama kehidupannya, kecuali ada gangguan pada anak tersebut.

Pakar pemerolehan bahasa menganggap bahwa pemerolehan sintaksis dimulai ketika kanak-kanak mulai dapat menggabungkan dua buah kata atau lebih (Chaer: 2003). Anak-anak pada tahap perkembangan sintaksis ini dapat menghasilkan kelas Pivot dan Kelas Terbuka. Kelas pivot adalah kata-kata fungsi (function words), sedangkan yang termasuk kelas terbuka adalah kata-kata isi (contents words) atau kata penuh ( full words).

Kelas Pipot hanya sedikit dan umumnya terdiri dari kata-kata yang frekuensi pemakaiannya dalam tuturan si anak dan secara perlahan makin bertambah. Kelas terbuka banyak dan jumlahnya mengandung semua kata dalam perkembangan si anak, yang tidak termasuk dalam kelas Pipot (Mar'at:2011).

Mean Length of Utterance (MLU) merupakan suatu alat untuk mengukur perkembangan sintaksis bahasa anak yang dikemukakan oleh Roger Brown yang telah secara luas digunakan sebagai indeks perkembangan sintaksis pada usia dini. MLU adalah jumlah elemen yang mengandung arti dalam kalimat yang diucapkan seorang anak. Secara empiris, bila MLU si anak meningkat, maka bentuk sintaksis akan lebih kompleks konstruksinya. Agar dapat menghitung MLU dari seorang anak, kita membutuhkan transkrip dari percakapan anak tersebut. MLU yang dimaksud disini adalah berdasarkan pada panjang rata-rata dari kalimat seorang anak yang diskor pada transkrip-transkrip ucapan spontan.

Brown menentukan tiap - tiap fase perkembangan berdasarkan MLU (Mean Length of Utterance) yang telah dikuasai anak. Tahapan MLU menurut Brown (dalam academid.mu.edu) dibagi menjadi beberapa tahapan yaitu:

Tabel 1 Tahapan MLU (Mean Length of Utterance)

\begin{tabular}{|c|c|c|}
\hline Tahap & Usia Rata - Rata (Bulan) & $\begin{array}{c}\text { MLU (Mean Length of } \\
\text { Utterance) }\end{array}$ \\
\hline I & $12-26$ & $1.0-2.0$ \\
\hline II & $27-30$ & $2.0-2.5$ \\
\hline III & $31-34$ & $2.5-3.0$ \\
\hline IV & $35-40$ & $3.0-3.75$ \\
\hline V & $41-46$ & $3.75-4.5$ \\
\hline VI & $47+$ & $4.5+$ \\
\hline
\end{tabular}


Untuk menghitung MLU seorang anak menurut Brown cara menghitung $M L U$ dapat dilakukan dengan beberapa langkah, pertama mengambil sampel sebanyak 50 atau 100 ujaran. Kedua, menghitung jumlah morfemnya. Ketiga, membagi jumlah morfem dengan jumlah ujaran, seperti pada rumus berikut:

MLU $=\frac{\text { Jumlah Morfem }}{\text { Jumlah Ujaran }}$

Setelah data dihitung, kemudian disesuaikan dengan tabel MLU yang dikemukakan oleh Brown, kemudian dianalisis apakah perkembangan sintaksis anak tersebut sudah sesuai dengan yang dikemukakan oleh Brown. Selain melihat tingkatan perkembangan sintaksis anak, jenis kata dan konstruksi kalimat yang telah dikuasai anak akan dianalisis.

Kelas kata dalam penelitian ini yang dianaliasis adalah verba, adjektiva, nomina, pronomina, numeralia, adverbia, interogativa, demonstrativa, artikula, preposisi, dan konjungsi. Penelitian ini juga melihat pola kalimat yang telah dapat dihasilkan oleh anak. Kalimat adalah satuan bahasa yang secara relatif berdiri sendiri, mempunyai pola intonasi final secara aktual maupun potensial terdiri dari klausa (Kridalaksana, 2001:92).

\section{METODOLOGI PENELITIAN}

Metode yang digunakan dalam penelitian ini adalah deskriptif kualitatif. Sumber data penelitian adalah anak berusia 4 tahun. Data penelitian dikumpulkan melalui hasil rekaman tuturan anak dengan orangtuanya (keluarganya), temannya, dan peneliti. Alat yang digunakan untuk merekam adalah tape recorder dan handphone. Hasil rekaman ditranskripkan dengan ejaan fonemik. Data yang dikumpulkan hanyalah 50 tuturan dari anak yang diambil sebagai sampel untuk mengukur $M L U$ anak tersebut. Analisis data dimulai dengan pentranskripsian data, penyeleksian data, pengklasifikasian data, dan pemaparan hasil analisi data.

\section{HASIL DAN PEMBAHASAN}

Anak yang menjadi subjek dalam penelitian ini adalah anak yang sehat secara jasmani dan rohani. Berdasarkan hasil rekaman data setelah melakukakan tahap pentranskripsian data, penyeleksian data, pengklasifikasian data diperoleh data seperti tabel di bawah ini.

Tabel 2 Tuturan yang Dihasilkan

\begin{tabular}{|l|c|c|c|}
\hline No & Jumlah Kata Per Tuturan & Jumlah Tuturan & Jumlah Morfem \\
\hline 1 & Tuturan satu kata & 2 & 2 \\
\hline 2 & Tuturan dua kata & 2 & 4 \\
\hline
\end{tabular}




\begin{tabular}{|l|l|c|c|}
\hline 3 & Tuturan tiga kata & 9 & 28 \\
\hline 4 & Tuturan empat kata & 6 & 26 \\
\hline 5 & Tuturan lima kata & 6 & 34 \\
\hline 6 & Tuturan enam kata & 6 & 40 \\
\hline 7 & Tuturan tujuh kata & 8 & 62 \\
\hline 8 & Tuturan delapan kata & 6 & 49 \\
\hline 9 & Tuturan sembilan kata & 2 & 19 \\
\hline 10 & Tuturan sepuluh kata & 3 & 31 \\
\hline & Jumlah & $\mathbf{5 0}$ & $\mathbf{2 9 5}$ \\
\hline
\end{tabular}

$$
\begin{aligned}
\text { MLU } & =\frac{\text { Jumlah Morfem }}{\text { Jumlah Tuturan }} \\
& =\frac{295}{50} \\
& =5,9
\end{aligned}
$$

Dari hasil perhitungan menunjukkan MLUnya berada pada tahap VI dengan 4,5+ panjang tuturan. Berdasarkan tahapan MLU anak tersebut sudah sesuai tingkat tuturannya.

Kelas kata merupakan bagian perkembangan dari sintaksis. Semakin tinggi MLU seorang anak maka dapat dikatakan semakin tinggi penguasaan bahasanya. Hal ini terlihat dari data yang telah dapat memproduksi sepuluh jenis kata yang dianalisis dan hanya satu jenis kata yang tidak dapat diproduksi yaitu kelas kata artikula. Berikut ini merupakan jenis kata yang dihasilkan oleh anak tersebut.

Tabel 2 Jenis Kata yang Dihasilkan

\begin{tabular}{|l|l|l|}
\hline NO & \multicolumn{1}{|c|}{ JENIS KATA } & \multicolumn{1}{c|}{ TUTURAN } \\
\hline 1 & Verba & Belajar \\
& & Dilipat \\
& & Masak \\
\hline 2 & Adjektiva & Merah \\
& & Putih \\
& & Kecil \\
& & Ramai \\
\hline
\end{tabular}




\begin{tabular}{|l|l|l|}
\hline 3 & Nomina & Foto \\
& & Nasi \\
& Kereta \\
& Ludo \\
\hline 4 & Pronomina & Ini \\
& & Itu \\
& & -nya \\
\hline 5 & Numeralia & Dua puluh \\
& & Seratus \\
& & Dua \\
& & Tiga \\
\hline 6 & Adverbia & Sudah \\
\hline 7 & Interogativa & Mana \\
& & Ke mana \\
\hline 8 & Demonstrativa & Di sana \\
\hline 9 & Preposisi & Ke \\
& & Di \\
\hline 10 & Konjungsi & Tapi \\
\hline & & \\
\hline
\end{tabular}

Kelas kata yang telah dapat dihasilkan dari anak tersebut adalah verba, adjektiva, nomina, pronomina, numeralia, adverbia, interogativa, demonstrativa, preposisi, dan konjungsi. Untuk jenis kata artikula tidak dapat dihasilkan oleh anak tersebut.

Penguasaan jenis kata akan mempengaruhi pola kalimat dan jenis kalimat yang dapat dihasilkan oleh anak. Perkembangan sintaksis anak dimulai dari penguasaan kelas kata, frasa, dan pola kalimat. Data menunjukan dengan tahapan MLU pada tingkatan VI telah dapat menghasilkan lima pola kalimat yaitu:

1) Ini (S) jatuh $(\mathrm{P})$.

2) Nazwa (S) gak bias(P) ke sana(K).

3) Semalam (K) aku (S) main (P) di sana (K).

4) Ayah (S) bawa (P) mainan (O) untuk Nazwa (K)

5) Nazwa (S) nulislah (P) tapi (Konj) Nazwa (S) capek (P). 
Dari lima pola kalimat tersebut menunjukkan bahwa penguasaan bahasa anak sudah bagus. Bahkan anak telah dapat menghasilkan kalimat majemuk setara dengan pola $\mathbf{S}+\mathbf{P}+\mathbf{k j}+\mathbf{S}$ + P. Konjungsi dari pola kalimat tersebut adalah tapi.

Data menunjukkan perkembangan sintaksisnya sangat berkembang pesat. Hal ini diakibatkan karena anak tersebut telah duduk di bangku sekolah PAUD (Pendidikan Anak Usia Dini). Lingkungan juga sangat mempengaruhi perkembangan bahasa seorang anak. Menduduki bangku sekolah akan membuat anak semakin mahir dalam berkomunikasi karena akan berinteraksi dengan orang lain. Selain lingkungan, pribadi seseorang juga mempengaruhi perkembangan bahasa anak. Berdasarkan pengamatan dan hasil wawancara dengan orang tuanya, anak tersebut memang sangat suka bercerita dan berinteraksi dengan orang lain. Brown mengatakan bahwa semakin tinggi MLU seorang anak maka semakin tinggi penguasaan bahasa anak tersebut. Hal ini juga terjadi pada anak tersebut yang menunjukkan penguasaan bahasanya sudah baik dengan tingkatan MLU yang sesuai dengan tingkat usianya.

Data dalam penelitian ini juga memperlihatkan bahwa anak telah dapat memproduksi kalimat dengan baik dan dapat menempatkan fungsi sintaksis dengan benar sehingga kalimat tersebut bermakna dan dapat dimengerti oleh lawan bicara. Selain itu, anak tersebut juga sudah dapat memproduksi kalimat pernyataan dan pertanyaan.

Penelitian ini memperlihatkan bahwa orang tua memiliki peran yang sangat besar dalam perkembangan bahasa anak. Berdasarkan pengamatan dan wawancara, orang tua selalu menggunakan bahasa yang teratur dan pelafalan yang benar. Di samping itu, orang tua sering mengajak anak untuk berbicara dan membacakan cerita.

\section{E. SIMPULAN}

Hasil penelitian menunjukkan bahwa anak tersebut berada pada tahap dalam VI Mean Length of Utterance (MLU) dengan panjang tuturan 5.9. Tingkatan MLU pada anak sudah sesuai dengan usianya. Jenis kata yang telah dihasilkan oleh anak tersebut adalah verba, adjektiva, nomina, pronomina, numeralia, adverbia, interogativa, demonstrativa, preposisi, dan konjungsi. Untuk jenis kata artikula tidak dapat dihasilkan.Pola kalimat yang telah dihasilkan adalah lima pola kalimat yaitu: $\mathrm{S}+\mathrm{P}, \mathrm{S}+\mathrm{P}+\mathrm{Ket}$, Ket $+\mathrm{S}+\mathrm{P}+\mathrm{Ket}, \mathrm{S}+\mathrm{P}+\mathrm{O}+$ Ket dan $S+P+k j+S+P$. Dari pola kalimat tersebut terlihat bahwa anak telah mampu menghasilkan pola kalimat majemuk setara. 


\section{DAFTAR PUSTAKA}

Chaer, Abdul. 2003. Psikolinguistik. Bandung: PT Rineka Cipta.

Darjowodjojo, Soenjono. 2010. Psikolinguistik: Pengatar Pemahaman Bahasa Manusia. Jakarta: Yayasan Obor Indonesia.

Kridalaksana, Harimurti. 2001. Jenis Kata dalam Bahasa Indonesia. Jakarta: PT. Gramedia Pustaka Utama.

Marsis, dan Witri Annisa. 2018. Pemerolehan Bahasa Anak di Sumatera Barat (Kajian Mean Length of Utterance [MLU]). Jurnal Lingua. Dalam journal.unnes.ac.id. Diakses tanggal 6 Mei 2020.

Nasution, Rini Sartika. 2019. Analisis Pemerolehan Sintaksis Menggunakan Teknik MLU (Mean Length of Utterance) Pada Anak Usia Lima Tahun. Diakses tanggal 5 Mei 2020.

Owens, J.E. 2008. Excerpt from Language Development: An Introduction. Dalam http://www.education.com/reference/article/acquisition-sentence-form. Diakses tanggal 30 Maret 2020. 